\title{
Diagenesis of Middle Jurassic Haldager Formation Sandstone in the Danish Subbasin, North Jutland
}

\author{
BJARNE LETH NIELSEN and HENRIK FRIIS
}

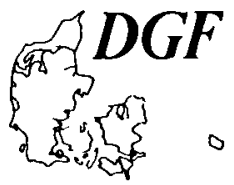

\begin{abstract}
Nielsen, B. L. \& Friis, H.: Diagenesis of Middle Jurassic Haldager Formation Sandstone in the Danish Subbasin, North Jutland, Bull. geol. Soc. Denmark, vol. 33, pp. 273-285. Copenhagen, February, 28th, 1985.

The Middle Jurassic Haldager Formation sandstones are mainly quartz arenites to subarkoses and sublitharenites. The diagenetic evolution of these sandstones is dominated by early quartz and kaolinite cementation which occur randomly distributed in the fluvio-deltaic sandstones whereas poikilotopic calcite cement is important in the marine deposits of the formation. Siderite, pyrite and Fe-hydroxides are minor, but common diagenetic minerals. The quartz and kaolinite precipitated from mildly acid formation water, which probably developed from the initial fresh water of the depositional environment. Where the sandstones are not sufficiently cemented, compaction may be important with development of pressure solution and crushing of quartz grains at burial depths of about $2000 \mathrm{~m}$. The porosity is generally good, but the presence of large amounts of authigenic kaolinite represents a potential risk of fines migration during production of fluids from the reservoir.
\end{abstract}

B. L. Nielsen, Dansk Olie og Gasproduktion A/S, Agern Alle 24-26, DK-2970 Hørsholm, Denmark. H. Friis, Department of Geology, University of Aarhus, DK-8000 Aarhus C, Denmark. July 23rd, 1984.

\section{Introduction}

The study of sandstone diagenesis has become of increasing importance in connection with the production of oil and gas from clastic reservoir rocks with marginal reservoir properties. The reduction of porosity and permeability caused by compaction and cementation is mainly controlled by the depth of burial and the lithological and chemical characteristics of the depositional environment. The diagenetic processes are thus the results of water-mineral interaction controlled by pressure, temperature and chemistry. A number of specific factors influence the diagenetic processes. For instance the presence of hydrocarbons within a reservoir strongly suppresses the alteration of the clastic mineral assemblage (Hancock \& Taylor, 1978).

The present paper gives the results of a regional study of the Middle Jurassic Haldager Formation sandstone reservoir in Mid- and North Jutland. The study forms part of an energy research programme, EFP 83, funded by the Danish Ministry of Energy.

Besides being a part of a general evaluation programme of Danish reservoir formations the study aims at an assessment of the Haldager Formation as a target for exploitation of geothermal energy. Since 1978 the Haldager Formation has been penetrated in two geothermal exploratory wells, Aars-1 and Fars $\emptyset-1$. Cores from these wells together with old cores from oil and gas exploration wells form the sample basis for the petrographic reservoir study. The samples were studied with emphasis on the occurrence and formation of the diagenetic minerals having a major influence on the porosity and permeability of the sandstones.

The location of the wells is shown in fig. 1 and the investigated samples are listed in table 1. All depths are in metres below Kelly Bushing (mbKB).

\section{Depositional environment and source area}

The Haldager Formation is subdivided into two members, the Haldager Sand overlain by the Flyvbjerg Member. The stratigraphy and distribution of the formation within the Danish area is presented by Michelsen (1978) and Koch (1983). Only the Haldager Sand is a potential reservoir. The Flyvbjerg Member is dominated by siltstone and claystone. The thickness of the Haldager Sand varies from 0 to ca. $150 \mathrm{~m}$ and within the 


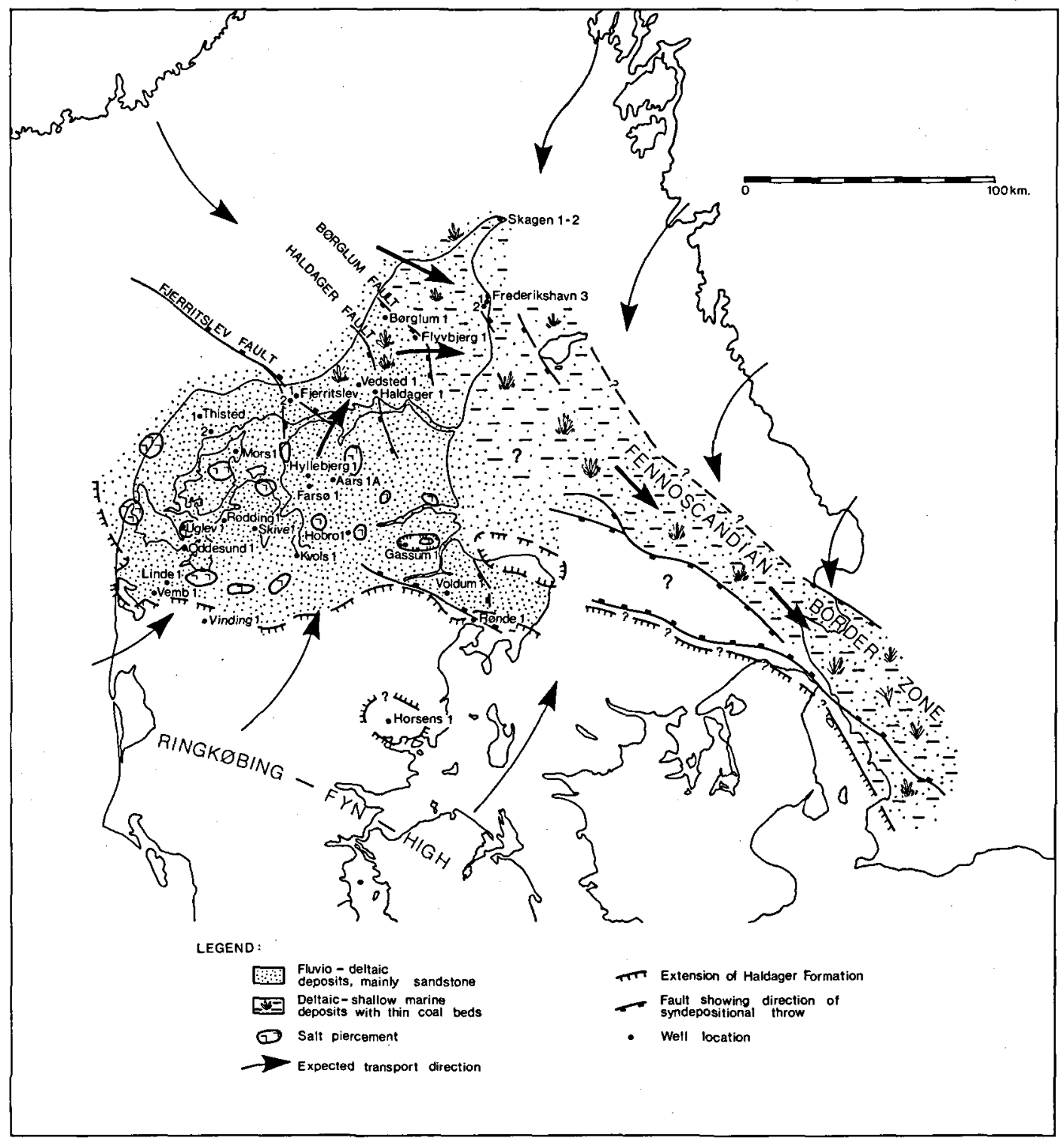

Fig. 1. Well location and distribution of the Haldager Formation in the Danish Subbasin (Modified after Koch (1983)).

Danish Subbasin the member is found at depths between 500 and $3000 \mathrm{~m}$.

The Mid-Kimmerian tectonic event resulted in an extensive regression from the Danish area, and only a narrow sea-way was kept open along the Fennoscandian High and connected to the Polish Trough (Michelsen 1978). Within this setting the Haldager Sand Member was deposited in fluvio-deltaic and shallow marine environments (Larsen 1966, Michelsen 1978, Koch 1983). Fol- lowing a renewed transgression the Flywbjerg Member was deposited in a deltaic-shallow marine environment (Michelsen 1978, Koch 1983).

The depositional pattern of the Haldager Sand was roughly controlled within two major systems, namely the narrow NW-SE trending sea-way and the northern flank of the uplifted RingkøbingFyn High (Koch 1983) (fig. 1). The narrow seaway occupying the Fennoscandian. Border zone was gradually filled by shifting prograding delta 
Table 1. Location of investigated samples from the Haldager Formation in North Jutland

\begin{tabular}{|c|c|c|}
\hline Well & $\begin{array}{l}\text { Sample Depth } \\
\text { mb KB }\end{array}$ & Remarks \\
\hline Aars-1 & 2462.0 & Flyvbjerg Member \\
\hline- & 2477.8 & Haldager Sand \\
\hline - & 2480.0 & - \\
\hline - & 2480.9 & - \\
\hline - & 2483.0 & - \\
\hline - & 2485.8 & - \\
\hline Fjerritslev-2 & 1268.8 & - \\
\hline Flyvbjerg-1 & 981.5 & - \\
\hline Frederikshavn-1 & 641.4 & Flyvbjerg Member \\
\hline- & 670.6 & - \\
\hline - & 676.5 & - \\
\hline- & 705.6 & Haldager Sand \\
\hline - & 713.2 & - \\
\hline- & 725.4 & - \\
\hline - & 731.5 & - \\
\hline - & 734.6 & - \\
\hline Frederikshavn-3 & 681.5 & - \\
\hline- & 683.0 & - \\
\hline- & 684.5 & - \\
\hline Haldager-1 & 1091.5 & Flyvbjerg Member \\
\hline- & 1096.0 & - \\
\hline- & 1097.0 & - \\
\hline- & 1155.0 & Haldager Sand \\
\hline- & 1221.0 & \\
\hline Skagen-2 & 418.0 & Flyvbjerg Member \\
\hline- & 428.0 & - \\
\hline- & 436.0 & Haldager Sand \\
\hline Thisted-3 & 996.6 & - \\
\hline - & 998.0 & - \\
\hline - & 1001.2 & - \\
\hline - & 1002.6 & - \\
\hline - & 1008.7 & - \\
\hline Vedsted-1 & 1146.0 & Flyvbjerg Member \\
\hline- & 1150.5 & Haldager Sand \\
\hline- & 1151.5 & - \\
\hline- & 1153.5 & - \\
\hline - & 1156.0 & - \\
\hline Uglev-1 & 918.0 & - \\
\hline- & 919.5 & - \\
\hline - & 920.5 & - \\
\hline - & 930.0 & - \\
\hline- & 935.0 & - \\
\hline- & 939.0 & - \\
\hline
\end{tabular}

lobes, partly supplied by rivers draining the Fennoscandian land-mass to the north and the northeast. The infill comprises sequences of deltaic coal-bearing sediments overlying and partly interfingering with shallow marine deposits (Gravesen et al. 1982, Koch 1983). Apparently there was a gradual retreat of the sea towards the southeast, and the northwestern part of the Fennoscandian Borderzone became an area of bypassing (Koch 1983).

Glauconite and marine fossils were found in most Haldager Sand samples from the wells northeast of the Fjerritslev Fault. These wells are all situated within the sea-way area (fig. 1).

The pronounced uplift of the Ringkøbing-Fyn High resulted in the development of a braided river plain on the northern flank. This river system deposited coarse, cross-bedded sandstones in a rather thin and probably wide spread blanket as evidenced from the wells Hyllebjerg 1, Fars $\emptyset 1$ and Aars 1 (Koch 1983). According to Koch (1983) this depositional pattern also includes the depocenter of the Haldager Formation, roughly situated midway between the Børglum Fault and the Fjerritslev Fault.

On the basis of log-motifs Michelsen (1978) suggested that the Haldager Sand is developed as coarsening-upwards cycles with deltaic affinity.

Sediments were transported northwards from the Ringkøbing-Fyn High and dominated the southern part of the Danish Subbasin as suggested by Koch (1983). Drainage systems from the north and northeast flowed into the lowlands of the Fennoscandian Borderzone and contributed to the interfingering of deltaic and shallow marine environments in the Danish-Polish Trough.

Following this model, the Haldager Sand should reflect the imprints of two major source areas, of which the southern one was probably the most important. The mineralogical maturity of the sandstone is high as also mentioned by Larsen (1966), so the clastic components give rather limited information on the source areas. The texture and composition of the lithic fragments suggest a source area of plutonic and high grade metamorphic rocks for both the terrestrial and marine parts of the Haldager Sand. Facies distribution and dipmeter analysis in the Farsø and Aars areas (M. Sørensen, personal communication) confirm a major source area to the south. This is in conflict with the findings of Larsen (1966) who, on the basis of mainly the heavy mineral assemblage argues for a single source area within the Fennoscandian Shield.

Dypvik \& Vollset (1979) describe the petrology of Jurassic sandstones from four off-shore locations in the western part of the NorwegianDanish Basin. Mineralogically these samples differ from the North Jutland samples in having 10$30 \mathrm{vol} \%$ of lithic fragments of volcanic rocks with an appearance similar to the Permian volcanics. Obviously volcanic rocks were not a pre- 


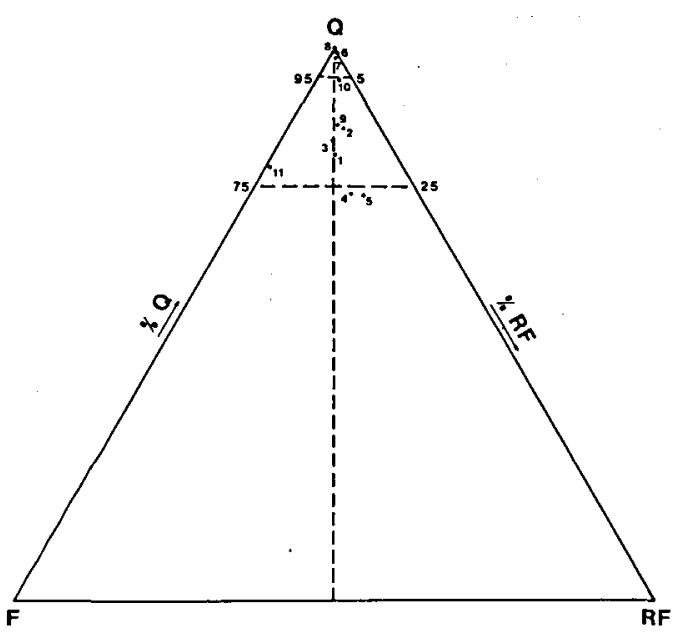

Fig. 2. Triangular plot of major constituents (quartz-feldsparrock fragments) in 11 thin sections. 1-5 Thisted-3, 6-8 Fars $\emptyset-1$, 9-10 Haldager-1, 11 Uglev-1.

dominant constituent in the source areas for the Haldager Sand in North Jutland.

\section{Petrography}

Applied analytical techniques

The petrography of the Haldager Formation sandstones was studied by means of optical microscopy, scanning electron microscopy (SEM) and X-ray whole rock diffraction analyses on 43 samples. Additionally 8 clay mineralogical analyses were carried out. The semiquantitative results of the optical mineralogy is presented in table 2. The mineralogical classification of the Haldager Formation sandstone is exemplified in the quartz-feldspar-rock fragment diagramme in fig. 2. The relative proportions of the essential constituents in 11 samples from Thisted-3, Fars $\varnothing$ 1, Haldager- 1 and Uglev-1 are plotted in the triangular diagramme. Following Folk (1980), the samples range from pure quarts arenites in Fars $\varnothing$ 1 to subarkose and sublitharenites in the other wells.

\section{Clastic minerals}

Although the investigated samples represent a number of sub-environments the petrographic character of the detrital components is fairly uniform. Quartz constitutes 70-90\%, alkali feldspar $2-7 \%$, clay $1-5 \%$ and muscovite $1-10 \%$. Acces- sory heavy minerals including opaques, zircon, rutile, sphene, garnet, tourmaline, pyroxene and hornblende, usually constitute less than $5 \%$ in total. Only very few grains of plagioclase were observed. Disseminated, allochthonous plant debris as either coal or lignite is common throughout the sandstone facies. Occasionally root or soil horizons (autochthonous coal) have been found. The sandstone is usually grey or greenish grey. No oriented grain fabric is observable except for an occasional alignment of muscovite flakes. The allogenic clay is preferably found in irregular schlieren, the deformation of which reveals compaction and sometimes bioturbation. The grain size varies from coarse silt to coarse sand with a clear predominance of fine grained sand. The sand is moderately to well sorted and the grains mainly subrounded. The usually grain supported fabric shows a wide range from point contacts to intermediate and long grain boundaries. Both the textural and the mineralogical maturity of the clastic components are moderate or high within the fluviatile deposits whereas the marine sandstones usually are less mature.

Authigenic minerals

The authigenic minerals in the samples constitute $5-25 \%$ (plate $1-2$ ). The assemblage is totally dominated by kaolinite and quartz as overgrowths; minor amounts of feldspar overgrowth, calcite, dolomite, siderite, pyrite and chlorite occur.

Kaolinite (plate 1) is present both in the fluviatile and the marine deposits, but with higher concentration in the former. It occurs either as replacement mineral of feldspars and or muscovite, or as well crystallized pore filling or pore lining cement. It may be vermicular or occur as platelets in disordered aggregates. The distribution of the kaolinite is irregular in both microscopic and macroscopic scale. In some samples the pore space is totally clogged with kaolinite. It is not possible to demonstrate any correlation between the amount of kaolinite and the present depth of burial. This is in agreement with observations by Iwuagwu \& Lerbekmo (1982), who describe strong variations in kaolinite cementation at constant depths in the Campanian Belly River Sandstone in Alberta.

Quartz overgrowth has been observed in about $50 \%$ of the samples investigated. Significant 
Table 2. Minerals identified by optical microscopy in the Haldager Formation sandstones

\begin{tabular}{|c|c|c|c|c|c|c|c|c|c|c|c|c|c|c|c|}
\hline $\begin{array}{l}\text { Legend: } \\
1 \text { 1 } 0-3 \% \\
2 \quad 3-10 \% \\
3 \quad 10-50 \% \\
450-100 \% \\
\times \text { present in } \\
\text { var. amount } \\
\text { + Flyvbjerg M. }\end{array}$ & & 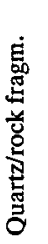 & 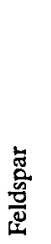 & $\stackrel{\mathscr{J}}{\mathrm{Z}}$ & 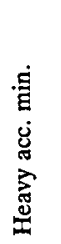 & 㞼 & 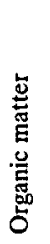 & 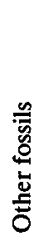 & ] & $\stackrel{0}{2}$ & 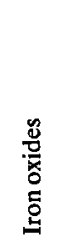 & $\begin{array}{l}\stackrel{\Xi}{\Xi} \\
\text { ठ․ } \\
\text { 总 }\end{array}$ & 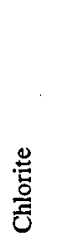 & 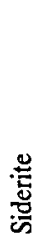 & 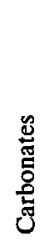 \\
\hline Well/depth (m) & & \multicolumn{7}{|c|}{ Terrigenous minerals } & \multicolumn{7}{|c|}{ Authigenic minerals } \\
\hline +Aars-1 & 2463.00 & 4 & & 2 & & 3 & & & $x$ & & 2 & & & & \\
\hline Aars-1 & 2477.75 & 4 & 1 & 1 & $x$ & & & & 2 & & 1 & & & & 2 \\
\hline- & 2480.00 & 4 & & & $x$ & & & & 2 & $x$ & & & & & \\
\hline- & 2480.30 & 4 & & & $x$ & & & & 2 & & & & & & \\
\hline- & 2482.00 & 4 & & 1 & 2 & & & & 3 & & 1 & & & & \\
\hline- & 2483.00 & 4 & & & $x$ & & & & 2 & & & & & & \\
\hline- & 2485.75 & 4 & & 1 & & $\times$ & & & 3 & $x$ & & & & & \\
\hline Fjerritslev-2 & 1268.80 & 4 & 2 & $x$ & $x$ & 1 & 2 & & 2 & $x$ & & $x$ & & & \\
\hline Flyvbjerg-1 & 981.50 & 4 & 2 & 1 & $x$ & 2 & & $x$ & 2 & & $x$ & $x$ & & $x$ & 1 \\
\hline Frederikshavn-1 & 641.40 & 4 & 3 & 1 & $x$ & $x$ & & & & & $x$ & $x$ & $x$ & & \\
\hline- & 670.60 & 4 & 2 & 1 & $x$ & 2 & & & $x$ & & $x$ & 1 & 1 & $x$ & \\
\hline- & 676.50 & 4 & 2 & 2 & $x$ & 3 & & & $x$ & & $x$ & $x$ & $x$ & & \\
\hline- & 705.60 & 4 & 1 & 2 & $x$ & 3 & & & $x$ & & $x$ & & & $x$ & $x$ \\
\hline- & 713.20 & 4 & 1 & 1 & $x$ & 2 & & & 3 & & $x$ & & & & \\
\hline- & 725.40 & 4 & 1 & 1 & $x$ & & & & 2 & & $x$ & & & & \\
\hline- & 731.50 & 4 & 2 & 1 & $x$ & 1 & $x$ & & 2 & & $x$ & $x$ & & & \\
\hline- & 734.60 & 4 & 2 & 1 & $x$ & & & & 2 & & $x$ & $x$ & & & \\
\hline Frederikshavn-3 & 681.50 & 4 & 2 & 1 & 1 & & $x$ & & 2 & $x$ & $x$ & $x$ & & & \\
\hline- & 683.00 & 4 & 1 & & $x$ & & & & 2 & $x$ & $x$ & $x$ & & & \\
\hline - & 684.50 & 4 & 1 & & $x$ & & 2 & & 2 & $x$ & $x$ & & & & \\
\hline +Haldager-1 & 1091.50 & 4 & 2 & & & 1 & & & & 1 & 1 & & 2 & 2 & 3 \\
\hline- & 1096.00 & 3 & 2 & 1 & $x$ & 2 & & & 1 & $x$ & 1 & $x$ & $x$ & $x$ & 3 \\
\hline- & 1097.00 & 4 & 2 & 2 & $x$ & 1 & 1 & & 2 & & $x$ & & & & $x$ \\
\hline Haldager-1 & 1155.00 & 4 & 2 & 2 & $\times$ & $x$ & & & $x$ & $x$ & $x$ & $x$ & $x$ & & \\
\hline- & 1221.00 & 4 & 2 & 1 & $x$ & $x$ & & & 3 & & $x$ & & & & \\
\hline Skagen-2 & 384.50 & 4 & 2 & 2 & $x$ & 2 & & $x$ & 2 & 1 & $x$ & $x$ & $x$ & 1 & 1 \\
\hline- & 386.50 & 3 & 2 & 3 & $x$ & 3 & & & 2 & 2 & & 2 & & & \\
\hline- & 418.00 & 4 & 2 & 3 & $x$ & 2 & & & $x$ & 1 & $x$ & 1 & & 1 & \\
\hline - & 428.00 & 3 & $x$ & & $x$ & 3 & & & & $x$ & 2 & & & 1 & $x$ \\
\hline- & 436.00 & 4 & 2 & 1 & $x$ & 1 & & & 2 & & $x$ & & $x$ & & \\
\hline Thisted-3 & 996.60 & 4 & 2 & 2 & 2 & $x$ & $x$ & & $x$ & $x$ & & & & & \\
\hline- & 998.00 & 4 & 2 & 1 & 2 & $x$ & $x$ & & $x$ & $x$ & & & $x$ & $x$ & \\
\hline- & 1001.20 & 4 & 2 & 1 & 1 & & $x$ & & $x$ & $x$ & & & & & \\
\hline- & 1002.40 & 4 & 2 & 2 & 2 & & $x$ & & $x$ & $x$ & & & & & \\
\hline- & 1008.70 & 4 & 2 & 2 & 1 & $x$ & $x$ & & $x$ & $x$ & & & & & \\
\hline Vedsted-1 & 1146.00 & $x$ & & & & $x$ & & & $x$ & & & & & & \\
\hline- & 1150.50 & 4 & 2 & & $x$ & & & & $x$ & & $x$ & $x$ & $x$ & & $?$ \\
\hline- & 1151.50 & 4 & 2 & & $x$ & & & & 2 & & 1 & & & & \\
\hline- & 1153.50 & 4 & 2 & 1 & & & & & 2 & $x$ & $x$ & & & & \\
\hline - & 1156.50 & 4 & 2 & 1 & $x$ & & & & & $x$ & $x$ & & & & \\
\hline Uglev-1 & 918.00 & 4 & 2 & 2 & $x$ & & $x$ & & 3 & 1 & $x$ & & & & \\
\hline- & 919.50 & 4 & 2 & 1 & $x$ & 1 & 2 & & 1 & 1 & 1 & & & & \\
\hline- & 920.50 & 4 & & $x$ & $x$ & & $x$ & & $x$ & $x$ & $x$ & & & & \\
\hline- & 930.00 & 4 & & & $x$ & 1 & 2 & & 2 & $x$ & & & & & \\
\hline- & 935.00 & 4 & & & $x$ & & & & 3 & $x$ & & & & & \\
\hline- & 939.00 & 4 & & & $x$ & & 1 & & 3 & 1 & & & & & \\
\hline
\end{tabular}

amounts are confined to the fluvial deposits. It occurs as euhedral and stepped surfaces reducing and partly closing the pore space and pore throats (plate 1). Quartz overgrowth generally leaves some interconnected pores. The textural relationship between kaolinite and authigenic quartz indicates that the quartz crystallized prior to or simultaneous with the kaolinite. Small de- 


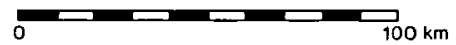

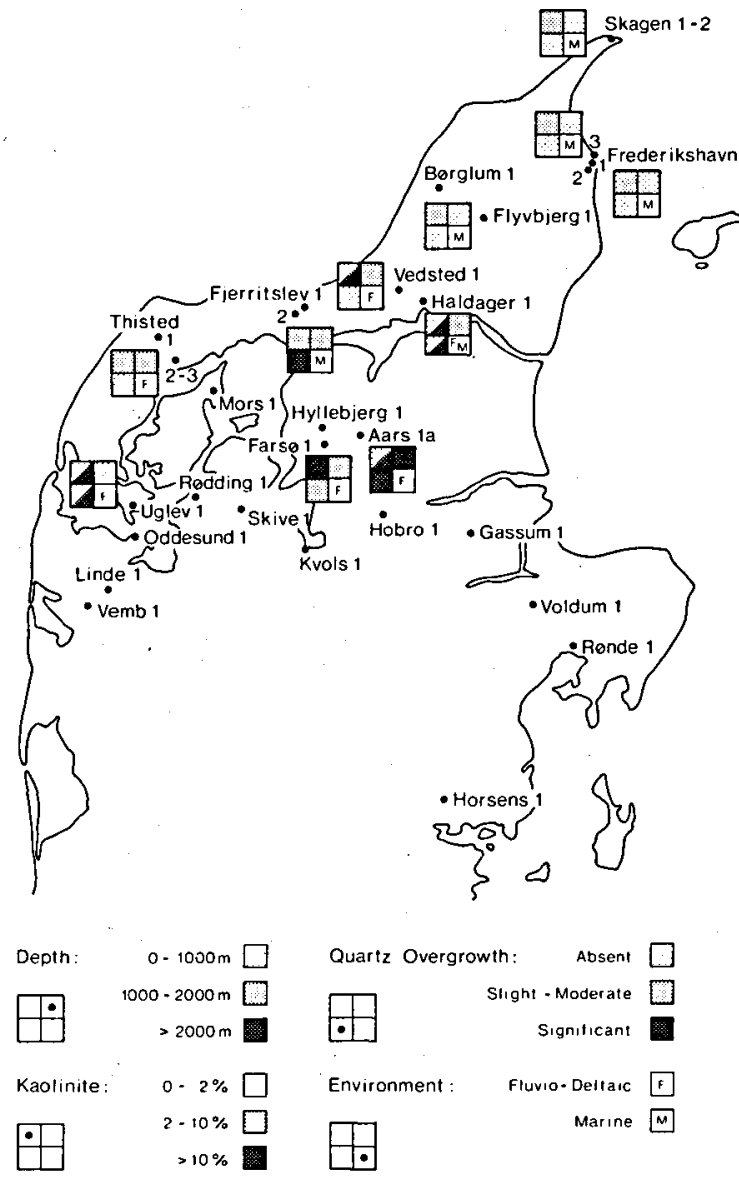

pressions in the quartz surface are often observed around single kaolinite crystals growing on the quartz grain.

Dissolution notches are very common on the overgrown quartz surfaces (plate $2 \mathrm{E}$ ).

The feldspars normally make up less than $10 \%$ of the sandstones. Together with muscovites the feldspars are dissolved and replaced to a varying degree (plate 2), and these minerals are regarded
Fig. 3. Deep wells in North Jutland which intersect the Haldager Formation. When cores are available information on depth, kaolinite- and quartz cementation and depositional environment is shown in the quadrangles at the well. Empty quadrangles indicate that cores are not available.

as the main sources for the $\mathrm{Al}$ and $\mathrm{Si}$ in the kaolinite and quartz overgrowth. Occasionally minor overgrowth on feldspars is seen. This overgrowth is probably late diagenetic and together with a minor amount of illite it represents a supply of $\mathrm{K}$ and a change of pore water chemistry to more alkaline conditions.

It is noteworthy that calcite occurs almost exclusively in the marine part of the Haldager Sand

Plate 1.

A. Pore lining and bridging clay (B); thin section: bar 50 microns; Uglev-1, $920.5 \mathrm{~m}$.

B. Pore lining and bridging clay (B); at contact surface between clastic grains; SEM, bar 5 microns; Uglev-1, $918.0 \mathrm{~m}$.

C. Authigenic kaolinite in strongly cemented sandstone; SEM; bar 10 microns; Vedsted-1, $1151.5 \mathrm{~m}$.

D. Euhedral quartz overgrowth and kaolinite cementation, pores still interconnected, SEM, bar 50 microns, Fjerritslev-2, $1268.8 \mathrm{~m}$.

E. Extensive quartz overgrowth which masks the original sedimentary texture and lowers the porosity and permeability considerably; SEM; bar 5 microns; Uglev-1, $920.5 \mathrm{~m}$.

F. Quartz overgrowth pre-dating crystallisation of authigenic kaolinite; SEM, bar 5 microns; Aars-1, $2482.0 \mathrm{~m}$. 

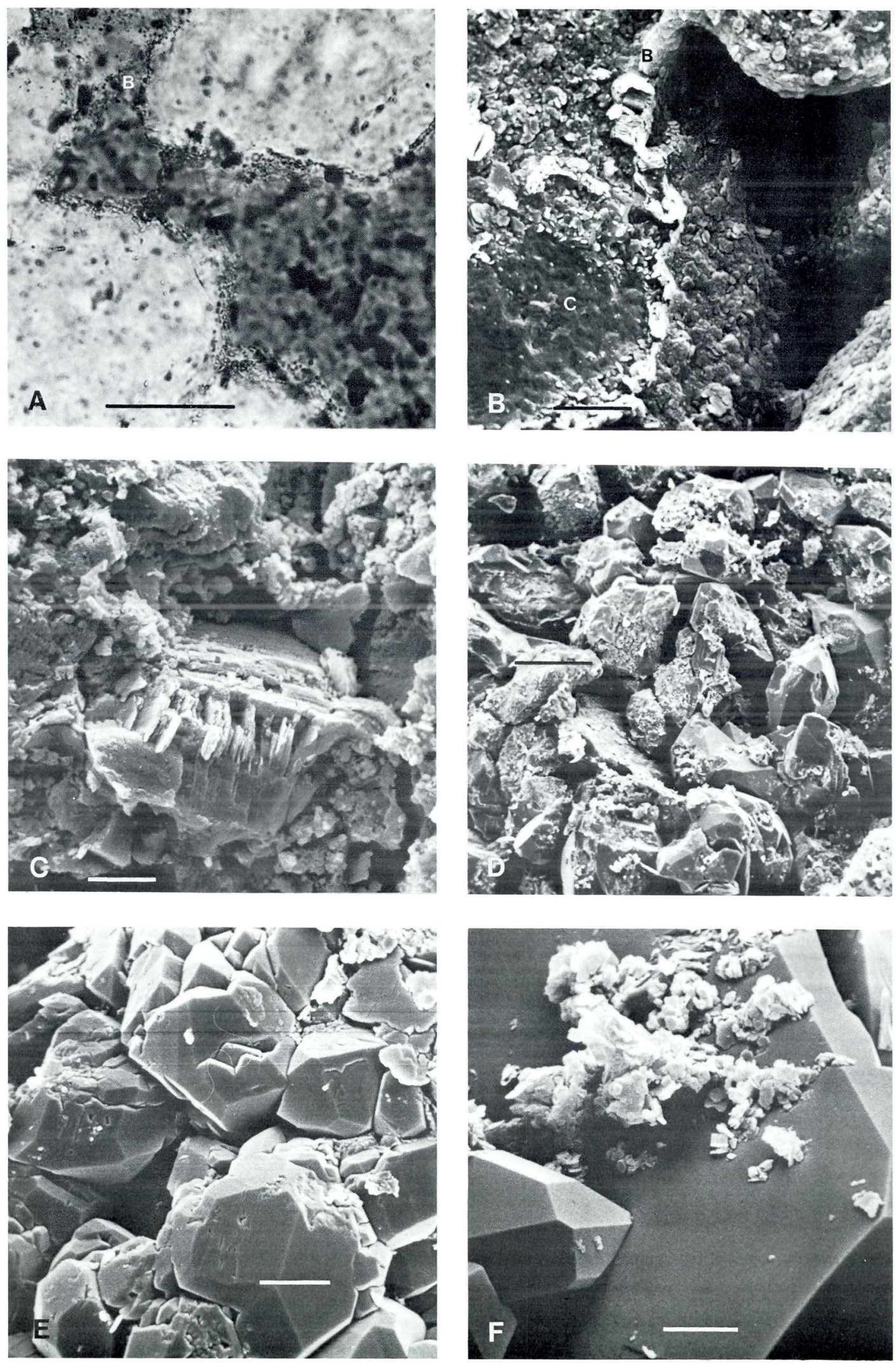
to the north east. Formation of calcite is usually favoured by increasing temperature and $\mathrm{pH}$ provided that a sufficient calcium source is present. Such conditions were presumably reached in the marine northeastern areas in the Danish Subbasin. Blanche \& Whitaker (1978) describe poikilotopic calcite in the marine Brent Sand Formation in the North Sea. In contrast to the Haldager Sand, calcite cementation is commonly seen in the Flyvbjerg Member. Although favourable pressure, temperature and $\mathrm{pH}$ conditions probably existed, the most likely reason for the absence of calcite in clean fluvial part of the Haldager Sand is the lack of an adequate Ca source. Such limitations were not present in the Flyvbjerg Member where seawater is an obvious $\mathrm{Ca}$ source.

Siderite, pyrite and Fe-oxides/hydroxides are minor, but common diagenetic minerals in the Haldager Sand (plate 4). Pyrite framboids and siderite are stable minerals under reducing conditions and independent of the $\mathrm{pH}$ (Berner 1970). They most probably belong to the early diagenetic stages. They are to a varying degree replaced by limonite/goethite. Minor rhombs of dolomite are observed in Aars-1, the only well where the Haldager Sand is intersected below a depth of $2000 \mathrm{~m}$.

Chlorite has been identified in a number of the samples (table 2), particularly from the Flyvbjerg Member. The chlorite may have formed from the kaolinite in the presence of excess $\mathrm{Fe}$ and $\mathrm{Mg}$ and a pink-green pleochroism often observed in the kaolinite may represent the initial stage of alteration to chlorite (plate 2).

The regional distribution of the most important diagenetic minerals is shown in fig. 3. The lack of depth control on the occurrence of authigenic kaolinite and quartz is obvious from the figure.

\section{Compaction}

Evidence of compaction is seen in samples from all depths of burial. With the exception of deformation of micas and soft rock fragments compaction diagenesis is not important in samples from depths of less than $1000 \mathrm{~m}$. In the deeper buried sandstones e.g. Fars $\emptyset-1$ and Aars-1 uncemented intervals have been strongly modified by mechanical compaction and pressure solution. Quartz grains have occasionally been extensively crushed or broken and pressure solution has taken place at grain contacts (plate 5A and B). The crushed and broken grains are seen to be firmly interlocked in a framework with strongly sutured grain boundaries (plate 5A and E). Dependant on the relative position of pressuretransfer points at upper and lower faces of grains they have been broken and a slight rotation may have opened the fractures (plate 5A). Such fractures were in some cases partly closed by later quartz or carbonate cement (plate $3 \mathrm{~A}$ and $\mathrm{D}$ ).

Further, the compaction evidently produced quartz silt by chipping and crushing of quartz grains (plate $1 C$ ). SEM reveals the grain surfaces subjected to pressure solution to be densely pitted (plate 3E).

\section{Discussion of diagenesis}

The diagenetic processes show no evidence of depth control, which implies that the formation of diagenetic minerals is related to the depositional environment rather than to the burial history.

In the following emphasis is put on the discussion on the diagenetic occurrence of quartz and kaolinite within the fluvio-deltaic sediments which predominate in the deeper parts of the basin.

Neoformation of both quartz and kaolinite is enhanced by mildly acidic ground water. Through oxidation and bacterial degradation of organic matter groundwater rapidly becomes acidic and the unstable minerals like feldspars and mica start to dissolve, releasing $\mathrm{K}, \mathrm{Al}$ and $\mathrm{Si}$

Plate 2.

A. Clay replacement of one component in perthite; SEM; bar 2 microns; Vedsted-1, $1153.5 \mathrm{~m}$.

B. Strongly dissolved feldspar giving secondary moldic porosity; SEM; bar 5 microns; Uglev-1, $918.0 \mathrm{~m}$.

C. Preferential clay replacement in feldspar. Thin section, bar 100 microns; Vedsted-1, $1150.5 \mathrm{~m}$.

D. Pore filling iron oxide cement; Thin section; bar 200 microns; Frederikshavn-1, $641.4 \mathrm{~m}$.

E. Quartz overgrowth with solution notches; SEM; bar, 5 microns; Haldager-1, $1221.0 \mathrm{~m}$.

F. Fraying and clay replacement of muscovite; SEM; bar 5 microns; Haldager-1, $1221.0 \mathrm{~m}$. 

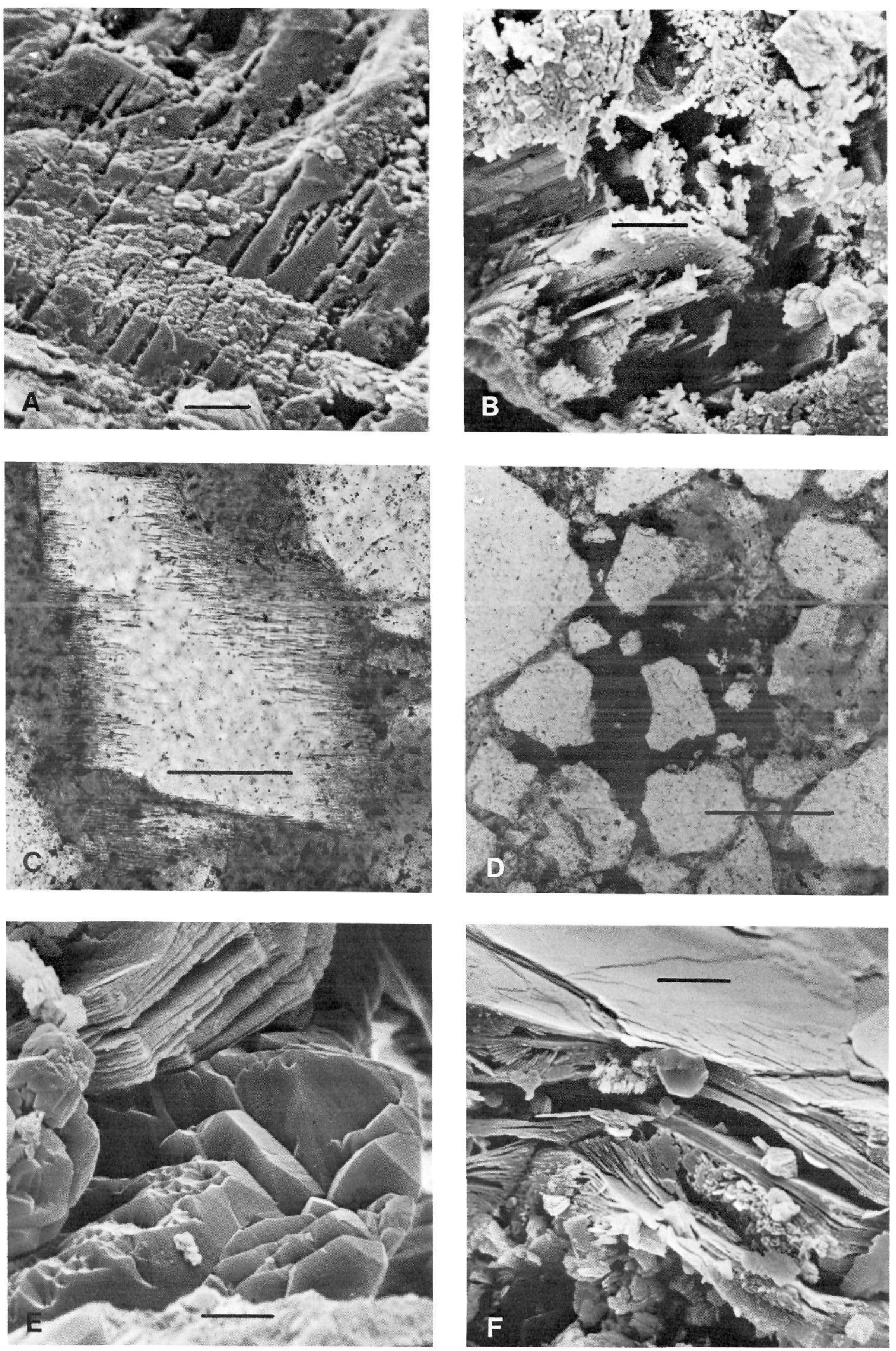
to the pore water. The subsequent quartz and kaolinite cementation is therefore related to the released cations as well as ions carried in from e.g. adjacent altered mudstone and siltstones, which during increasing compaction dewatered into the sandstone.

The cementation thus becomes a result of the local drainage pattern and the composition of local and neighbouring rocks. The processes have started immediately following deposition. The presence of organic debris probably also favoured the neoformation of quartz in maintaining a $\mathrm{pH}$ less than 9-10. At $\mathrm{pH}$ higher than 9 (Blatt et al. 1972) silica starts to dissolve. Such conditions were only reached very locally, as shown by the presence of corrosion notches.

Formation of diagenetic kaolinite in Jurassic sandstones in the North Sea has been discussed by Blanche \& Whitaker (1978), Hancock and Taylor (1978), Sommer (1978) and Dypvik and Vollset (1979). Neoformation of quartz together with and prior to authigenic kaolinite are features commonly reported. As in North Jutland, the kaolinite is usually well crystallised and occurs in stacks and accordions in the pore space. Usually kaolinite and quartz are early diagenetic minerals which form from alteration products of feldspar and mica. In the North Sea area the kaolinite formation was to a varying degree followed by illite replacement. This process was partly controlled by the local migration of, or saturation with, hydrocarbons (Sommer, 1978). Formation of illite plays a neglegible role in the Jutland wells. In the SEM and thin section studies possible minor amounts of illite may be distinguished by morphology (ridges on detrital grains and bridging minerals). Mixed layer clays may also occur, but cannot be accurately determined by the applied techniques. Marked $10 \AA$ peaks on the x-ray diffractogrammes are interpreted as detrial muscovite rather than authigenic illite. Clay mineralogical analyses of 8 samples from Fars $\varnothing-1$, Aars-1 and Thisted-3 showed that the dominant clay mineral was kaolinite. Minor amounts of illite and mixed layer clays were identified in Thisted3. The lack of extensive illitization is most likely due to insufficient temperatures at the relatively shallow depths.

The interpretation above implies that the Haldager Sand is most likely to be cemented where it was originally well drained and carried a high amount of organic debris. As a result of the reactions themselves (mineral one $+\mathrm{H} \rightleftarrows$ mineral two + metal cation) the $\mathrm{pH}$ later increased and authigenic illite and feldspar overgrowth may locally occur. Such second phase reactions have been observed in a few samples and are probably of a local nature.

It is suggested that the majority of the diagenetic processes within the fluvio-deltaic Haldager Sand are of a very early nature and resulted from fairly simple chemical reactions between pore fluids and the detrital grains. Where such early cementation did not take place the sediment became strongly compacted during increasing subsidence and pressure solution and crushing of quartz grains are locally important phenomena. The silica released by pressure solution was to some degree re-precipitated as quartz cement adjacent to the solution contacts, but apparently the major part of released silica was carried away to re-precipitate elsewhere. As the majority of the fluviatile Haldager Sand subarkoses contain organic debris and may originally have been well drained and oxygenated they form a favourable environment for early cementation with quartz and kaolinite. In contrast the calcite formed in the marine sands.

Porosity measurements, $\log$ and core analysis by Priisholm (1983) show an average decrease in porosity of $7.8 \%$ (absolute) per 1000 meters for the Haldager Sand. The present study shows that the steady decrease in porosity with depth is due mainly to mechanical compaction and crushing. Contrary to Priisholm we believe that the formation of quartz and kaolinite belongs to an early

Plate 3.

A. Broken quartz with pressure solution contacts $(\mathrm{P})$. The cracks were opened during further compaction. At $\mathrm{C}$ a crack is filled by carbonate cement. Thin section; bar 200 microns; Aars-1, $2480.7 \mathrm{~m}$.

B. Quartz grain (Q) with concoidal fractures and pressure solution contact (P). SEM; bar 40 microns; Aars-1. $2480.9 \mathrm{~m}$.

C. Concoidal fracture in quartz incipient chipping of silt sized quartz, SEM; bar 4 microns; Fars $\varnothing-1,1958.8 \mathrm{~m}$.

D. Broken quartz and later formation of quartz overgrowth (arrows); SEM; bar 20 microns; Vedsted-1, $1153.5 \mathrm{~m}$.

E. Quartz with pitted surface produced by pressure solution. Note the microstylolitic surface (arrows); SEM; bar 15 microns; Aars-1, $2480.0 \mathrm{~m}$. 

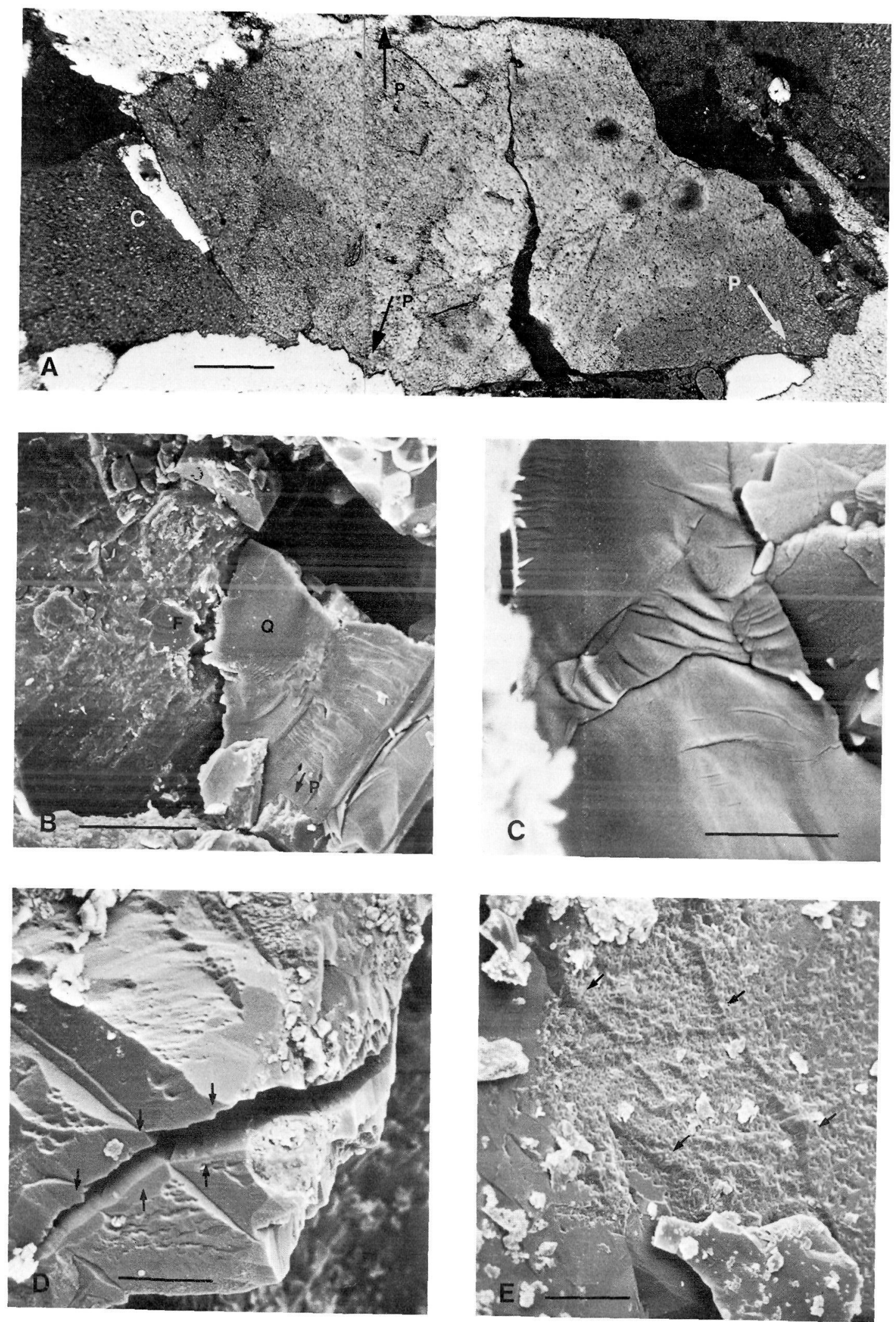
diagenetic stage and that quartz overgrowth only in some cases was a more important cause for porosity decline than was compaction.

\section{Conclusion}

The following conclusions on the diagenesis of the Haldager Sand and its influence on the reservoir rock properties are as follows:

1. The original mineralogy of the Haldager Sand is simple. The rocks are quarts arenites and subarkoses with a small amount of muscovite and heavy minerals. The source area for the fluvio-deltaic deposits is indicated to be located to the south. The maturity of the sediment could indicate that they were recyclet from older sediments on the Ringkøbing-Fyn High. The marine dominated north-eastern part of the area was probably sourced from the Fennoscandian Shield.

2. The diagenetic alteration of the sandstones with respect to the major mineral phases is simple.

a. Early formation of kaolinite is seen in all wells. The distribution is controlled by local composition and drainage conditions. Formation of kaolinite is partly suppressed within the shallow marine environment to the north-east, in which calcite cement may predominate.

b. Formation of quartz overgrowths predates and overlaps with kaolinite precipitation. Quartz overgrowths are predominantly found in the deltaic-fluvial environment. The control of its irregular distribution within this regime is unknown. Causality in its distribution may be established through an improved data base.

3. The permeability of a reservoir rock is strongly influenced by growth morphology of the cementing minerals. Thus kaolinite cemented sandstone is expected to suffer a stronger reduction in permeability than is quartz cemented sandstone. More core analyses are needed to quantify this relationship for the Haldager Sand.

4. The abundant occurrence of kaolinite forms a potential risk of fines migration during a production of reservoir fluids. The loosely stacked accordions of authigenic kaolinite may easily be detached from the clastic grain surfaces and during transport eventually block pore throats.

Acknowledgements. A considerable part of the optical microscopy was carried out by Christian Knudsen for which he is kindly acknowledged. The core samples from the old oil and gas exploration wells were provided by the Geological Survey of Denmark (DGU). DGU also prepared the thin sections and the XRD-analyses.

\section{Dansk sammendrag}

Studiet af sandstensdiagenese er gennem de seneste år blevet tillagt stadig større betydning $\mathrm{i}$ takt med en stigende interesse for produktion af olie og gas fra sandstensreservoirer med mere marginale reservoiregenskaber. Som et led i en regional undersøgelse af potentielle varmtvandsreservoirer $i$ den danske undergrund er der foretaget en vurdering af den diagenetiske omdannelsesgrad af den mellemjurassiske Haldager Formation.

Den petrografiske sammensætning af Haldager Formationens sandlag er simpel og starkt domineret af kvarts (fig. $3 \mathrm{og}$ table 2), medens feldspat, glimmer, bjergartsfragmenter og tungmineraler udgør underordnede bestanddele. I formationens fluviatile og deltaiske aflejringer forekommer to vasentlige typer af diagenetisk omdannelse, nemlig cementering med mineralerne kvarts og kaolinit, og stark kompaktion af sandlagene de steder, hvor de på stor dybde stadig er ucementerede. Kvarts- og kaolinitcement optræder på stort set alle undersøgte dybder, men ikke systematisk. Blandt prøver fra samme boring og næsten samme dybde kan nogle være meget tat cementerede, medens andre er næsten uden cement. I disse ucementerede områder har kompaktionen sat sit stærkeste præg. Hvor Haldager Formationen ligger dybest (Farsø 1 og Aars 1) er kompaktionen blevet særlig kraftig ved, at klastiske korn er knust og ved udbredte trykopløsninger af kvarts. Kvartscementeringen ses som dannelse af ofte store, veludviklede krystaller på de klastiske kvartskorn. I modsætning til kaolinitcementering bidrager disse kvartsovervoksninger forholdsvis lidt til permeabilitetsreduktionen.

Kaolinit cementen er meget uregelmassigt fordelt og udfylder pletvis porerne fuldstandigt. Krystallerne kan findes i uregelmæssige aggregater eller velordnede, f.eks. i ormelignende stabler. Kaoliniten ses lejlighedsvis at replacere feldspat eller glimmer.

De indbyrdes vækstrelationer mellem kvarts og kaolinit viser, at kvartsen er vokset før og delvis samtidig med kaoliniten. I de marint aflejrede Haldager sandsten forekommer poikilitisk calcit, hvorimod dette aflejringsmiljø var ugunstigt for nyvækst af kvarts og kaolinit.

Feldspatkornene er $i$ hele basinområdet $i$ almindelighed meget stærkt nedbrudte. Enkelte ses at være replaceret af kaolinit, medens der i mange tilfælde er opstået sekundær porøsitet gennem en næsten fuldstandig opløsning af feldspaten. Siderit, pyrit og jernhydroxider forekommer almindeligt, men normalt $i$ meget beskedne mængder, medens nydannet feldspat er sjælden.

Der ses ikke nogen tydelig relation mellem cementeringsmønstret med kvarts og kaolinit og dybden, og det konkluderes at denne cementering er foregået tidligt efter aflejring og er betinget af forhold $i$ aflejringsmiljøet. Kaoliniten kan med sine løst pakkede krystalstabler udgøre en risiko for tilstopning af reservoiret ved pumpning, idet de små krystaller kan rives løs, føres med vandstrømmen og danne propper i porehalsene, hvorved permeabiliteten hurtigt falder. 


\section{References}

Berner, R. A. 1970: Sedimentary pyrite formation. Am. Jour. Sci., vol. 268, 1-23.

Blatt, H. 1979: Diagenetic processes in sandstones. In Scholle, P. A. \& Schluger, P. R. (eds): Aspects of diagenesis. Spec. Publ. 26, SEPM, Tulsa, Oklahoma, 443 pp.

Blanche, J. B. and Whitaker, J. H. McD 1978: Diagenesis of part of the Brent Sand Formation (Middle Jurassic) of the northern North Sea Basin. J. Geol. Soc. Lond., vol. 135, 73-82.

Dypvik, H. and Vollset, J. 1979: Petrology and diagenesis of Jurassic Sandstones from Norwegian Danish Basin, North Sea. AAPG Bull, vol. 63, No. 2, 182-193.

Folk, R. L. 1980: Petrology of sedimentary rocks. Hemphill Publ. Co, Austin, Texas, 182 pp.

Gravesen, P., Rolle, F. and Surlyk, F. 1982: Lithostratigraphy and sedimentary evolution of the Triassic, Jurassic and Lower Cretaceous of Bornholm, Denmark. Geol. Surv. Denmark, Ser. B. No. 7, 51 p.
Hancock, N. J. and Taylor, A. M. 1978: Clay mineral diagenesis and oil migration in the Middle Jurassic Brent Sand Formation. J. Geol. Soc. Lond., vol. 135, 69-72.

Iwuaqwu, C. J. and Lerbekmo, J. F. 1982: The petrology of the basal Belly River sandstone reservoir, Pembina Field, Alberta, Bull. Can. Petr. Geol., vol. 30, No. 3, 187-207.

Koch, J. O. 1983: Sedimentology of Middle and Upper Jurassic sandstone reservoir of Denmark. Geol. Mijnbouw, 62, 115-129.

Larsen, G. 1966: Rhaetic-Jurassic-Lower Cretaceous sediments in the Danish embayment. Geol. Surv. Denmark, Ser. II, No. 91.

Michelsen, O. 1978: Stratigraphy and distribution of Jurassic deposits of the Norwegian-Danish Basin. Geol. Surv. Denmark, Ser. B, No. 2.

Priisholm, S. 1983: Geothermal reservoir rocks in Denmark. Geol. Surv. Denmark, Árbog 1982, 73-86.

Sommer, F. 1978: Diagenesis of Jurassic sandstones in the Viking Graben. J. Geol. Soc. Lond. vol. 135, 63-67. 